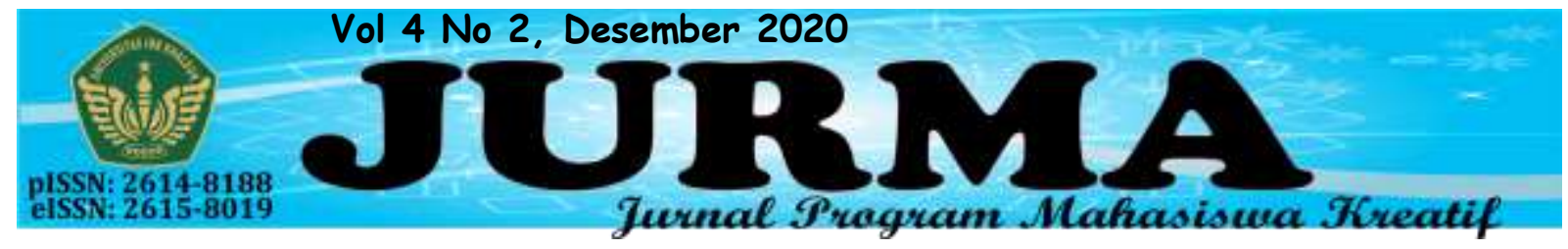

\title{
OPTIMALISASI PENCEGAHAN COVID-19 DI PERUMAHAN VISAR INDAH PRATAMA 2 CIBINONG KECAMATAN CIBINONG KABUPATEN BOGOR TAHUN 2020.
}

\author{
Hana Maulina ${ }^{1}$ dan Fenny Raharyanti ${ }^{2}$ \\ hanamaulin@gmail.com ${ }^{1}$ \\ fennyrisnawan@ymail.com ${ }^{2}$ \\ Dosen Fakultas Ilmu Kesehatan Universitas Ibn Khaldun Bogor ${ }^{1,2}$
}

\begin{abstract}
ABSTRAK
Covid-19 (coronavirus disease 2019) adalah penyakit yang disebabkan oleh jenis coronavirus baru yaitu Sars-CoV-2, yang dilaporkan pertama kali di Wuhan, provinsi Hubei, China pada 8 Desember 2019. Sampai saat ini virus corona menjadi masalah serius yang tengah dihadapi oleh berbagai negara di belahan dunia karena jumlah kasus setiap harinya yang terus meningkat. Tujuan dari kegiatan Kuliah Kerja Nyata Gagasan Tertulis Mandiri (KKN-GTM) ini adalah untuk mengoptimalisasi pencegahan Covid-19 di RT 04 RW 13 Perumahan Visar Indah Pratama 2 Cibinong Kecamatan Cibinong Kabupaten Bogor. Metode dalam pengumpulan data berdasarkan hasil kuesioner berupa pretest dan post-test. Populasinya adalah warga di RT 04 RW 13 Perumahan Visar Indah Pratama 2 Cibinong, dengan sampel sebanyak 20 responden. Berdasarkan hasil pretest dan post test dapat diambil kesimpulan bahwa nilai rata-rata dari hasil pretest pengetahuan covid-19 sebesar 95,30\% sedangkan dari hasil post testnya sebesar $99,70 \%$. Nilai rata-rata dari hasil pretest perilaku pencegahan covid19 sebesar 87,5\% sedangkan dari hasil post test sebesar 94,5\%. Hal ini menunjukkan tingkat pengetahuan dan perilaku warga terhadap pencegahan covid-19 cukup meningkat, tetapi masih ada beberapa warga yang belum memahami pengetahuan tersebut dan menerapkan perilaku untuk mencegah penularannya.
\end{abstract}

Kata Kunci: covid-19, pencegahan, pengetahuan, perilaku

\begin{abstract}
Covid-19 (2019 coronavirus disease) is a disease caused by a new type of corona virus, namely Sars-CoV-2 which was first reported in Wuhan, Hubei Province, China on December 8, 2019. Until now, the corona virus has become a serious problem faced by various countries around the world because the number of cases every day continues to increase. The purpose of this Independent Written Idea Real Work Lecture (KKN-GTM) is to optimize the prevention of Covid-19 in RT 04 RW 13 Visar Indah Pratama 2 Cibinong Housing, Cibinong District, Bogor Regency. Methods in data collection based on the results of the questionnaire in the form of pretest and post-test. The population is residents in RT $04 R W 13$ Visar Indah Pratama 2 Cibinong Housing, with a sample of 20 respondents. Based on the results of the pretest and posttest, it can be concluded that the average value of the pre-test results of Covid-19 knowledge is 95.30 while the post-test results are 99.70. The average value of the pre-test results for covid-19 prevention behavior was 87.5, while the post-test results were
\end{abstract}


94.5. This shows that the level of knowledge and behavior of residents regarding the prevention of Covid-19 has increased, but there are still some residents who do not understand this knowledge and apply behaviors to prevent transmission.

\section{Keywords: covid-19, prevention, knowledge, behavior}

\section{PENDAHULUAN}

Pada awal tahun 2020, kejadian serempak di dunia dengan lahirnya virus jenis baru corona, yang dikenal dengan covid-19. Asal mula adanya virus ini, diketahui berasal dari Wuhan, provinsi Hubei, China pada 8 Desember 2019. Sampai saat ini virus corona menjadi masalah serius yang tengah dihadapi oleh berbagai negara di belahan dunia karena jumlah kasus setiap harinya yang terus meningkat (Yuliana, 2020). Berdasarkan perkembangan data pada tanggal 20 September 2020, bahwa yang terkonfirmasi terinfeksi covid-19 secara global terdapat 30.675.675 kasus dengan 954.417 tingkat kematian $(3,1 \%)$ di 215 Negara Terjangkit dan 180 Negara Transmisi lokal atau yang dapat diartikan sebagai wilayah yang melaporkan kasus konfirmasi yang penularan virus ini diketahui secara lokal di wilayahnya. (WHO dan PHEOC Kemenkes RI, 2020)

Virus corona telah masuk ke Indonesia pada 2 Maret 2020. Pemerintah Indonesia telah mengumumkan terdapat 2 kasus warga Indonesia yang terjangkit covid-19. Sampai sat ini, berdasarkan data pada tanggal 20 September 2020, bahwa di Indonesia yang terkonfimasi positif berjumlah 248.852, yang sembuh 180.797dan 9.677 pasien yang meninggal. (Satuan Tugas Penanganan covid-19, 2020). Berdasarkan data World Health Organization (WHO) tahun 2020, menyebutkan bahwa pandemi covid-19 bisa menyerang dan terjadi pada semua kelompok umur, tetapi pada kelompok usia lanjut lebih rentan terjangkit virus ini. kematian yang diakibatan oleh virus corona terjadi pada kelompok usia lebih dari 60 tahun yaitu $95 \%$ dan lebih dari $50 \%$ terjadi pada kelompok usia 80 tahun. Hal ini dapat dilihat bahwa 8 dari 10 kematian yang memiliki riwayat medis penyerta atau yang disebut komordibitas seperti penyakit jantung dan paru-paru, tekanan darah tinggi, diabetes atau penyakit kronis lainnya.

Tanda dan gejala umum yang biasa di alami oleh pasien covid-19 dapat mennimbulkan gangguan saluran pernapasan yang memiliki tingkat keparahannya cepat memburuk dan membuat tidak nyaman pada yang terinfeksi virus ini. Dalam hal ini pasien mengalami demam, batuk dan sesak napas. Rata-rata masa inkubasi atau yang dimana waktu yang diperlukan sejak terinfeksi hingga pasien menunjukkan gejala bisa 5 sampai 6 hari hingga terpanjang mencapai 14 hari. Pada pasien yang mengalami kasus berat dapat menyebabkan peradangan paru-paru yang disebabkan oleh infeksi (pneumonia), sindrom pernapasan akut, gagal ginjal dan bahkan bisa menyebabkan kematian. Sebagian besar kasus yang dilaporkan mengalami demam, kesulitan bernafas dan hasil pemeriksaan dari rotngen yang dilakukan di rumah sakit menujukkan infiltrat pneumonia luas di kedua paru. (Kemenkes RI, 2020).

Berdasarkan penelitian yang sudah dilakukan, bahwa virus ini dapat menular melalui kontak erat dan droplet atau 
percikan air liur orang yang sakit saat batuk dan bersin. Orang yang memiliki kontak erat dengan pasien covid-19 termasuk juga pada orang yang merawat pasein tersebut seperti tenaga medis mempunyai resiko yang lebih tinggi untuk tertular. (Kemenkes RI, 2020)

$$
\text { Menurut Menkes }
$$

menyatakan bahwa situasi covid-19 sampai saat ini masih dalam risiko yang sangat tinggi, baik di tingkat global maupun nasional. Mengingat perkembangan vaksin yang tujuannya digunakan untuk bisa mencegah seseorang terjangkit virus ini masih dalam proses, hal ini yang menyebabkan dunia harus mempersiapkan diri untuk berdampingan dan menjalani kehidupan sehari-hari dengan covid-19.

Tindakan yang bisa dilakukan untuk mencegah dan mengurangi penyebaran covid-19 yang bisa diterapkan di masyarakat maupun pelayanan kesehatan, hal ini dengan melakukan kebersihan tangan dengan cara mencuci tangan menggunakan sabun dan air mengalir, menghindari menyentuh wajah seperti mata, hidung dan mulut, menerapkan etika batuk atau bersin, menggunakan masker, menjaga jarak fisik minimal 1 meter dan meningkatkan daya tahan tubuh dengan menerapkan perilaku hidup bersih dan sehat seperti mengkonsumsi gizi seimbang, berolahraga dan lain sebagainya. (Kemenkes RI, 2020).

Berdasarkan sumber data dari juru bicara covid-19 Kota Bogor Tahun 2020, menyatakan bahwa pada tanggal 21 September 2020 kasus yang terinfeksi virus ini terus meningkat sebanyak 1049, sembuh 700, masih terinfeksi atau sakit 310, dan 39 pasien yang meninggal. Hal ini yang dinyatakan positif dengan pemeriksaan PCR (Polymerase Chain Reaction) swab test. Sejak tanggal 15
Maret 2020, Wali Kota Bogor mengeluarkan surat edaran Nomor 443.1/1057-umum tentang pencegahan penyebaran corona virus disease (Covid19) di Kota Bogor, tujuan dari adanya surat edaran dibuat untuk menjaga dan melindungi masyarakat Kota Bogor. Namun, sampai saat ini kasus yang terinfeksi virus ini terus meningkat. Oleh sebab itu, peran masyarakat juga sangat dibutuhkan untuk memutuskan mata rantai virus ini.

Dilatarbelakangi situasi ini, Univesitas Ibn Kaldun Bogor sebagai tridharma perguruan tinggi mengadakan kegiatan Kuliah Kerja Nyata Gagasan Tertulis Mandiri (KKN-GTM) yang dimana sebagai program yang wajib diikuti oleh mahasiswa secara perorangan di lingkungan tempat tinggal mahasiswa, hal ini dilaksanakan dalam bentuk pengabdian kepada masyarakat. Kegiatan ini berkaitan dengan penanganan pandemi covid-19 untuk mendukung dan menguatkan program penanggulangan dan pencegahan yang telah diakukan oleh pemerintah Indonesia.

Berdasarkan situasi tempat kegiatan KKN-GTM yang akan dilaksanakan oleh mahasiswa secara perorangan, peneliti melakukan kegiatan ini di Perumahan Visar Indah Pratama 2 Cibinong Kecamatan Cibinong Kabupaten Bogor. Di wilayah tersebut terdapat 1 kasus yang terinfeksi covid-19 dan diumumkan pada tanggal 20 September 2020. Saat ini peneliti melaksanakan kegiatan ini hanya berada di lingkungan RT 04 RW 13. Tujuan dari kegiatan KKN-GTM ini adalah untuk mengoptimalisasi pencegahan covid19 di RT 04 RW 13 Perumahan Visar Indah Pratama 2 Cibinong Kecamatan Cibinong Kabupaten Bogor. 


\section{METODE PELAKSANAAN}

Penelitian ini merupakan studi deskriptif dengan mengumpulkan data berdasarkan hasil kuesioner berupa pretest dan post-test, data ini merupakan data primer. Data primer merupakan data yang didapatkan dari hasil pengisian kuesioner kepada responden yang sesuai dengan krieria pada kegiatan KKN-GTM ini.

Populasi dalam kegiatan ini adalah warga RT 04 RW 13 Perumahan Visar Indah Pratama 2 Cibinong Kecamatan Cibinong Kabupaten Bogor, dengan jumlah 204 warga yang terdiri dari 48 kepala keluarga. Sampel dalam kegiatan ini adalah 20 warga yang merupakan perwakilan dari masing-masing keluarga dengan metode pengambilan sampel menggunakan purposive sampling.

Adapun kriteria inklusi yang ditetapkan pada penelitian ini yaitu warga yang berada di dalam grup RT 04 RW 13, mampu berkomuikasi dengan baik, bersedia menjadi responden dan bersedia mengikut proses kegiatan KKN-GTM yang sedang dilaksanakan. Adapun kriteria eksklusi penelitian ini yaitu warga yang tidak berada di dalam grup RT 04 RW 13, tidak mampu berkomuikasi dengan baik, tidak bersedia menjadi responden dan

tidak bersedia mengikut proses kegiatan KKN-GTM yang sedang dilaksanakan.

Penelitian ini dilakukan melalui 3 tahap dengan kurun waktu 1 bulan yaitu pada tanggal 01-30 September 2020 di lingkungan RT 04 RW 13 Perumahan Visar Indah Pratama 2 Cibinong.

Tahap pertama, peneliti melakukan analisis situasi, tahap ini merupakan langkah awal dalam perencanaan kegiatan sehingga dapat mengetahui gambaran tentang permasalahan yang ada di lingkungan tersebut. Langkah selanjutnya dapat merumuskan masalah secara jelas dan menentukan prioritas masalah yang akan dijadikan sebagai program kegiatan. Tahap ini juga mengajukan perizinan dan melakukan koordinasi kepada ketua RT 04 RW 13 untuk melaksanakan kegiatan. Berdasarkan hasil dari analisis situasi dilingkungan tersebut masih banyaknya warga yang berkumpul atau berkerumun dan tidak menggunakan masker saat ke luar rumah dan lain sebagainya. Dalam hal ini masih banyak warga yang belum menerapkan pencegahan covid-19.

Tahap kedua, yaitu membuat poster yang digunakan untuk memberikan edukasi mengenai pencegahan covid-19 dan membuat kuesioner melalui google formulir berupa pretest yang akan diberikan saat kegiatan edukasi melalui media online ini belum di laksanakan dan post-test akan diberikan saat kegiatan edukasi sudah dilaksanakan. Hasil post-test yang akan dibandingkan dengan hasil pretest digunakan sebagai salah satu alat ukur keberhasilan kegiatan yang sudah dilaksanakan dan mengetahui seberapa jauh pengaruh dari pemberian edukasi yang telah dilakukan.

Tahap ketiga, yaitu melaksanakan program yang sudah direncanakan dengan memberikan pretest pada tanggal 14 september, setelah itu di tanggal 15-20 september memberikan informasi mengenai edukasi pencegahan covid-19 melalui media poster dan pada tanggal 21 september memberikan post-test. Kegiatan ini dilaksanakan secara online melalui grup whatsapp RT 04 RW 13 yang berjumlah 40 warga. Warga yang bersedia untuk mengisi pretest dan post-test berjumlah 20 responden, hal ini dijadikan sebagai sampel. Selain itu, peneliti melakukan pemantauan setiap harinya untuk 
mengetahui perkembangan di lingkungan tersebut.

\section{HASIL dan PEMBAHASAN}

Kuesioner yang diberikan berupa pretest dan post-test sebagai cara dalam pengumpulan data yang dilakukan, menjadi tahap akhir dalam kegiatan KKNGTM ini. kuesioner ini terdiri dari 27 pertanyaan mengenai pengetahuan dan perilaku. Pada kuisioner juga terdapat lembar persetujuan menjadi responden.

Tabel 1. Distribusi Nilai Frekuensi Pretest dan Post test Pengetahuan Covid-19

\begin{tabular}{|c|c|c|c|}
\hline \multirow{2}{*}{ No } & \multirow{2}{*}{ Daftar pertanyaan } & \multicolumn{2}{|c|}{ Jawaban Benar (\%) } \\
\hline & & Pretest & Post test \\
\hline \multicolumn{4}{|c|}{ Pengetahuan } \\
\hline 1 & $\begin{array}{l}\text { Covid-19 } \\
\text { singkatan adalah } \\
\text { "coronavirus disease } \\
2019 " \text { atau penyakit } \\
\text { yang disebabkan oleh } \\
\text { virus corona pada } \\
2019\end{array}$ & 100 & 100 \\
\hline 2 & $\begin{array}{l}\text { Covid-19 adalah } \\
\text { penyakit menular } \\
\text { yang disebabkan oleh } \\
\text { jenis coronavirus }\end{array}$ & 100 & 100 \\
\hline 3 & $\begin{array}{l}\text { Covid-19 adalah } \\
\text { penyakit yang baru } \\
\text { ditemukan }\end{array}$ & 95 & 100 \\
\hline 4 & $\begin{array}{l}\text { Demam merupakan } \\
\text { salah satu gejala } \\
\text { covid-19 }\end{array}$ & 95 & 100 \\
\hline 5 & $\begin{array}{l}\text { Batuk kering } \\
\text { merupakan salah satu } \\
\text { gejala covid-19 }\end{array}$ & 90 & 100 \\
\hline 6 & $\begin{array}{l}\text { Rasa lelah yang terus } \\
\text { menerus merupakan } \\
\text { salah satu gejala } \\
\text { covid-19 }\end{array}$ & 80 & 100 \\
\hline 7 & $\begin{array}{lr}\text { Covid-19 } & \text { dapat } \\
\text { menular dari orang } & \text { tidak } \\
\text { yang } & \text { tala } \\
\text { menunjukkan gejala }\end{array}$ & 95 & 100 \\
\hline 8 & $\begin{array}{lr}\text { Masa } & \text { inkubasi } \\
\text { dimulai } & \text { dari } \\
\text { seseorang } & \text { terkena }\end{array}$ & 100 & 100 \\
\hline
\end{tabular}

\begin{tabular}{|c|c|c|c|}
\hline & $\begin{array}{l}\text { covid-19 yaitu selama } \\
14 \quad \text { hari sampai } \\
\text { menimbulkan gejala }\end{array}$ & & \\
\hline 9 & $\begin{array}{lr}\text { Virus } & \text { penyebab } \\
\text { covid-19 ditularkan } \\
\text { melalui } \quad \text { kontak } \\
\text { dengan tetesan kecil } \\
\text { (droplet) dari saluran } \\
\text { pernapasan }\end{array}$ & 90 & 95 \\
\hline 10 & $\begin{array}{lr}\text { Covid-19 } & \text { dapat } \\
\text { bertahan di } & \text { benda } \\
\text { hingga beberapa jam }\end{array}$ & 100 & 100 \\
\hline 11 & $\begin{array}{l}\text { Orang yang lebih tua } \\
\text { rentan terkena covid- } \\
19\end{array}$ & 100 & 100 \\
\hline 12 & $\begin{array}{l}\text { Orang yang } \\
\text { mempunyai riwayat } \\
\text { penyakit asma rentan } \\
\text { terkena covid-19 }\end{array}$ & 100 & 100 \\
\hline 13 & $\begin{array}{lr}\text { Orang } & \text { yang } \\
\text { mempunyai } & \text { riwayat } \\
\text { penyakit } & \text { diabetes } \\
\text { rentan terkena covid- } \\
19\end{array}$ & 90 & 100 \\
\hline 14 & $\begin{array}{lr}\text { Orang } & \text { yang } \\
\text { mempunyai } & \text { riwayat } \\
\text { penyakit } & \text { jantung } \\
\text { rentan terkena covid- } \\
19\end{array}$ & 85 & 100 \\
\hline 15 & $\begin{array}{l}\text { Menjaga jaga jarak } \\
\text { minimal } 1 \text { meter } \\
\text { dengan orang lain } \\
\text { saat di kerumunan } \\
\text { dapat mencegah } \\
\text { penularan covid-19 }\end{array}$ & 100 & 100 \\
\hline 16 & $\begin{array}{l}\text { Menggunakan } \\
\text { masker saat keluar } \\
\text { rumah } \\
\text { mencegah penularan } \\
\text { covid-19 }\end{array}$ & 100 & 100 \\
\hline 17 & $\begin{array}{l}\text { Sering mencuci } \\
\text { tangan menggunakan } \\
\text { sabun dengan air } \\
\text { bersih dan mengalir } \\
\text { dapat mencegah } \\
\text { penularan covid-19 }\end{array}$ & 100 & 100 \\
\hline & Rata-Rata & 95,30 & 99,70 \\
\hline
\end{tabular}


Berdasarkan hasil dari 17 pertanyaan mengenai pengetahuan terdapat 9 pertanyaan dijawab benar oleh responden baik pretest dan post test dengan nilai persentase $(100 \%)$ yang terdiri dari beberapa pertanyaan yaitu covid-19 adalah singkatan dari "coronavirus disease 2019" atau penyakit yang disebabkan oleh virus corona pada 2019, covid-19 adalah penyakit menular yang disebabkan oleh jenis coronavirus, masa inkubasi dimulai dari seseorang terkena covid-19 yaitu selama 14 hari sampai menimbulkan gejala, covid-19 dapat bertahan di benda hingga beberapa jam, orang yang lebih tua rentan terkena covid-19, orang yang mempunyai riwayat penyakit asma rentan terkena covid-19, menjaga jaga jarak minimal 1 meter dengan orang lain saat di kerumunan dapat mencegah penularan covid-19, menggunakan masker saat keluar rumah dapat mencegah penularan covid19, sering mencuci tangan menggunakan sabun dengan air bersih dan mengalir dapat mencegah penularan covid-19. Sedangkan jawaban terendah yang terdapat pada pretest yaitu dengan nilai persentase $(80 \%)$ mengenai rasa lelah yang terus menerus merupakan salah satu gejala covid-19.

Tabel 2. Distribusi Nilai Frekuensi Pretest dan Post test Perilaku Pencegahan Covid-19.

\begin{tabular}{|l|l|c|c|}
\hline \multirow{2}{*}{ No } & \multicolumn{2}{|c|}{ Daftar pertanyaan } & \multicolumn{2}{|c|}{ Jawaban Benar (\%) } \\
\cline { 3 - 4 } & \multicolumn{1}{|l|}{$\begin{array}{l}\text { Pretest } \\
\text { Saya tidak memakai } \\
\text { masker pada saat } \\
\text { berkumpul dengan } \\
\text { orang lain }\end{array}$} & 75 & 85 \\
\hline 2 & $\begin{array}{l}\text { Saya berjabat tangan } \\
\text { dengan orang lain }\end{array}$ & 75 & 90 \\
\hline 3 & $\begin{array}{l}\text { Saya menjaga jarak } \\
\text { minimal 1 meter } \\
\text { dengan orang lain saat } \\
\text { di luar rumah }\end{array}$ & 100 & 100 \\
\hline 4 & $\begin{array}{l}\text { Saya mencuci tangan } \\
\text { dengan air yang }\end{array}$ & 100 & 100 \\
\hline
\end{tabular}

\begin{tabular}{|c|c|c|c|}
\hline & $\begin{array}{lr}\text { mengalir } & \text { dan } \\
\text { menggunakan } & \text { sabun } \\
\text { sebelum makan } & \end{array}$ & & \\
\hline 5 & $\begin{array}{l}\text { Saya memakai masker } \\
\text { saat ke warung }\end{array}$ & 75 & 95 \\
\hline 6 & $\begin{array}{l}\text { Saya mencuci tangan } \\
\text { dan berganti pakaian } \\
\text { setelah tiba di rumah }\end{array}$ & 100 & 100 \\
\hline 7 & $\begin{array}{l}\text { Saya tidak segera } \\
\text { merendam pakaian } \\
\text { setelah keluar rumah }\end{array}$ & 65 & 90 \\
\hline 8 & $\begin{array}{lr}\text { Saya lebih } & \text { suka di } \\
\text { rumah jika tidak ada } \\
\text { kepentingan } \\
\text { keluar rumah }\end{array}$ & 100 & 100 \\
\hline 9 & $\begin{array}{lr}\text { Saya selalu menjaga } \\
\text { kesehatan } & \text { tubuh } \\
\text { dengan berolahraga }\end{array}$ & 85 & 85 \\
\hline 10 & $\begin{array}{l}\text { Saya merubah pola } \\
\text { makan dengan } \\
\text { makanan-makanan } \\
\text { yang bergizi }\end{array}$ & 100 & 100 \\
\hline & Rata-Rata & 87,5 & 94,5 \\
\hline
\end{tabular}

Berdasarkan hasil dari 10 pertanyaan mengenai perilaku pencegahan covid-19 terdapat 5 pertanyaan dijawab benar oleh responden baik pretest dan post test dengan nilai persentase $(100 \%)$ yang terdiri dari beberapa pertanyaan yaitu saya menjaga jarak minimal 1 meter dengan orang lain saat di luar rumah, saya mencuci tangan dengan air yang mengalir dan menggunakan sabun sebelum makan, saya mencuci tangan dan berganti pakaian setelah tiba di rumah, saya lebih suka di rumah jika tidak ada kepentingan untuk keluar rumah, saya merubah pola makan dengan makanan-makanan yang bergizi. Sedangkan jawaban terendah yang terdapat pada pretest yaitu dengan nilai persentase $(65 \%)$ mengenai saya tidak segera merendam pakaian setelah keluar rumah.

Media yang digunakan untuk melaksanakan kegiatan KKN-GTM ini yaitu berupa poster untuk memberikan edukasi mengenai pencegahan covid-19 
kepada warga RT 04 RW 13 di Perumahan

Visar Indah Pratama 2 Cibinong.

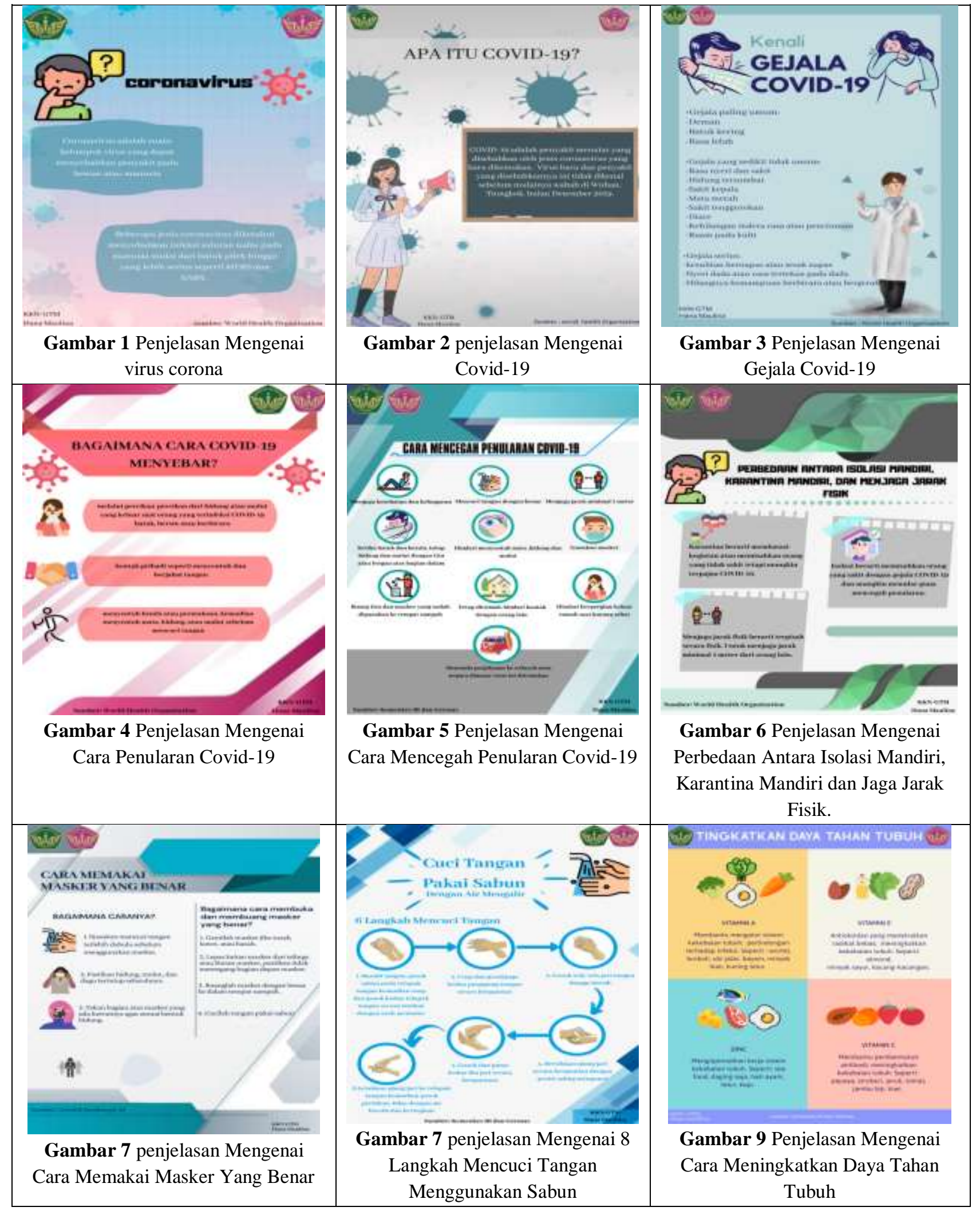

Gambar 1 menjelaskan tentang virus corona yang dimana virus ini dapat menyebabkan penyakit pada hewan dan manusia. jika virus ini menyerang pada 
manusia akan menyebabkan infeksi pada saluran pernapasan yang akan mengalami gejala yang ditandai dengan batuk dan pilek hingga bisa menyebabkan kondisi yang lebih serius. Kemudian virus corona jenis baru yang ditemukan ini menyebabkan covid-19. (WHO, 2020)

Gambar 2 memberikan informasi mengenai covid-19, bahwa covid-19 ini merupakan penyakit menular yang disebabkan oleh jenis virus corona dan menjadi sebuah darurat kesehatan pada masyarakat di belahan dunia. Asal mula adanya virus ini, diketahui berasal dari Wuhan, provinsi Hubei, China pada 8 Desember 2019. Covid-19 sampai saat ini menjadi sebuah pandemi yang terjadi di belahan dunia dan jumlah kasus setiap harinya yang terus meningkat. (WHO, 2020)

Gambar 3 memberikan informasi mengenai gejala covid-19. Rata-rata masa inkubasi atau yang dimana waktu yang diperlukan sejak terinfeksi hingga pasien menunjukkan gejala bisa 5 sampai 6 hari hingga terpanjang mencapai 14 hari. Masing-masing orang yang terserang covid-19 akan mengalami gejala yang berbeda-beda, mulai dari gejala yang paling umum, sedikit tidak umum bahkan bisa mengalami gejala serius. Orang-orang yang berusia lanjut, mempunyai penyakit riwayat medis seperti tekanan darah tinggi atau yang biasa disebut hipertensi, gangguan jantung dan paru-paru dan diabetes ini sangat rentan terinfeksi covid19 dan bisa mengalami penyakit yang lebih serius. Virus ini juga bisa menyebabkan orang yang terifeksi tidak menunjukkan gejala. (WHO, 2020).

Gambar 4 memberikan informasi mengenai cara penularan covid-19. Sampai saat ini, jumlah kasus yang terserang covid-19 terus meningkat, karena dilihat dari cara peularannya pun berbeda-beda sehingga membuat masyarakat semakin waspada dan khawatir. Virus ini dapat menyebar melalui percikan-percikan dari hidung atau mulut seseorang yang terinfeksi covid-19 saat batuk, bersin atau berbicara, Melakukan kontak pribadi yaitu berjabat tangan dengan orang lain dan menyentuh benda atau permukaan yang sudah terinfeksi oleh virus ini. hal ini sangat penting bagi masyarakat untuk memahami dalam upaya pengendalian atau pencegahan. (WHO, 2020).

Gambar 5, memberikan informasi mengenai cara mencegah penularan covid19. Dalam upaya menangani wabah virus corona yang semakin meluas, peran masyarakat sampai saat ini sangat penting dan dibutuhkan untuk memutuskan mata rantai virus ini. Hal yang bisa dilakukan untuk mencegah penularan covid-19 dengan mengikuti anjuran dari pemerintah yaitu menjaga kesehatan dan kebugaran, mencuci tangan dengan benar, menjaga jarak fisik minimal 1 meter, menerapkan etika batuk dan bersin, hindari menyentuh mata, hidung dan mulut, gunakan masker, buang tisu dan masker yang sudah digunakan ke tempat sampah, tetap dirumah dan hindari kontak mata dengan orang lain, hindari berpergian keluar rumah saat sedang tidak sehat dan menunda perjalanan ke wilayah yang dimana virus ini ditemukan . (Kemenkes, 2020).

Gambar 6, memberikan informasi mengenai perbedaan antara isolasi mandiri, karantina mandiri dan jaga jarak fisik. Isolasi mandiri bertujuan untuk memisahkan orang yang sakit dengan menujukkan gejala covid-19. Karantina mandiri berarti membatasi atau memisahkan orang yang memungkinkan terpajan covid-19. Sedangkan jaga jarak 
fisik berarti terpisah secara fisik dengan orang lain. Minimal dalam menerapkan jaga jarak yaitu 1 meter. Dengan adanya tindakan ini diharapkan dapat mengurangi dan mencegah penyebaran covid-19 (WHO, 2020).

Gambar 7 menjelaskan tentang cara memakai masker dengan baik dan benar. Seperti yang kita ketahui bahwa menggunakan masker saat pandemi merupakan hal yang wajib untuk dipakai terutama saat keluar rumah. Hal ini guna mencegah penularan covid-19 (Kemenkes, 2020).

Gambar 8 menjelaskan langkahlangkah dalam mencuci tangan menggunakan sabun. Salah satu perilaku hidup bersih dan sehat yang harus diterapkan dalam kehidupan sehari-hari untuk menjaga kesehatan dan kebersihan

\section{PEMBAHASAN}

Poster merupakan media yang digunakan untuk membantu proses memberikan informasi atau edukasi mengenai pencegahan covid-19 dalam menjalankan kegiatan KKN-GTM ini. Hal ini karena poster bisa memudahkan pembaca untuk memahami informasi yang telah disampaikan oleh peneliti.

Dapat diketahui dari hasil pretest dan post test mengenai pengetahuan covid-19 dengan nilai tertinggi menunjukkan persentase $(100 \%)$ bahwa beberapa warga RT 04 RW 13 sudah memahami dan memiliki pengetahuan yang baik. Sedangkan jawaban terendah yang terdapat pada pretest yaitu dengan nilai persentase (80\%) hal ini menujukkan ada beberapa warga yang masih belum mengetahui dan paham akan pengetahuan covid-19.

Hasil dari pretest dan post test mengenai perilaku pencegahan covid-19 dengan nilai tertinggi menunjukkan pribadi adalah mencuci tangan dengan baik dan benar, agar tangan bersih dan terhindar dari kuman atau penyakit. Karena tangan merupakan media yang sangat ampuh untuk berpindahnya penyakit. Jika daya tahan tubuh kita lemah maka dengan mudahnya vius akan masuk ke tubuh kita (Kemenkes, 2020).

Gambar 9, memberikan informasi mengenai cara meningkatkan daya tahan tubuh. Hal ini merupakan salah satu pencegahan agar seseorang tidak mudah terinfeksi covid-19, ada banyak cara yang bisa dilakukan untuk meningkatkan daya tahan tubuh yaitu dengan mengonsumsi makanan yang bergizi untuk meningkatkan daya tahan tubuh tetap sehat seperti mengonsumsi vitamin A,C,E dan Zinc. (Kemenkes, 2020)

persentase $(100 \%)$ bahwa beberapa warga RT 04 RW 13 sudah memiliki perilaku yang baik dan paham untuk melakukan pencegahan. Sedangkan jawaban terendah yang terdapat pada pretest yaitu dengan nilai persentase $(65 \%)$ hal ini menujukkan ada beberapa warga yang masih belum menerapkan perilaku pencegahan covid19.

Terbentuknya perilaku seseorang dalam hal ini pada perilaku kesehatan, dimulai dengan adanya pengalamanpengalaman seseorang dan adanya faktor ekternal yang berupa lingkungan fisik dan non fisik. setelah mempunyai pengalaman dan lingkungan tersebut kemudian diketahui lalu dipersepsikan dan diyakini seseorang sehingga dapat menimbulkan motivasi yang mendorong seseorang untuk bertindak yang pada akhirnya akan diwujudkan dengan menerapkan perilaku sehat (Notoatmodjo, 2010). 


\section{KESIMPULAN}

Pemahaman warga terhadap pengetahuan covid-19 dapat dilihat dari hasil pretest dan post test. Nilai tertinggi dengan persentase $(100 \%)$ sedangkan nilai terendah dengan persentase $(80 \%)$. Nilai rata-rata dari hasil pretest sebesar 95,30\% sedangkan dari hasil post test sebesar 99,70\%.

Pada hasil pretest dan post test mengenai perilaku pencegahan covid-19 menunjukkan terdapat nilai tertinggi dengan persentase $(100 \%)$ sedangkan nilai

\section{DAFTAR PUSTAKA}

Dinas Komunikasi dan Informatika Kota Bogor. (2020). Informasi Covid-19. http://www.covid19.kotabogor.go.id/

Dinas Komunikasi dan Informatika Kota Bogor. (2020).Pusat Informasi dan Koordinasi Covid-19 Pemerintah Kota

Bogor.http://www.covid19.kotabogo r.go.id

Direktur jenderal Pencegahan Dan Pengendalian penyakit (2020). Pedoman pencegahan dan Pengendalian Coronavirus Disease (Covid-19) Revisi ke-3. Jakarta: Kemenkes RI.

Kemenkes RI. (2019). Media Informasi resmi Terkini Penyakit Infeksi Emerging. https://covid19.kemkes.go.id/.

Kementerian Dalam Negeri. (2020). Pedoman Umum Menghadapi Pandemi Covid-19 Bagi Pemerintah terrendah dengan persentase $(65 \%)$. Nilai rata-rata dari hasil pretest sebesar $87,5 \%$ sedangkan dari hasil post test sebesar $94,5 \%$.

Hal ini menunjukkan tingkat pengetahuan dan perilaku warga terhadap pencegahan covid-19 cukup meningkat, tetapi masih ada beberapa warga yang belum memahami pengetahuan tersebut dan menerapkan perilaku untuk mencegah penularannya.

Daerah (Pencegahan, Pengendalian, Diagnosis Dan Manajemen). Jakarta: Tim Kerja Kementerian dalam Negeri.

Kementerian Pemberdayaan Perempuan dan Perlindungan Anak RI. (2020). Panduan Perlindungan Lanjut Usia Berperspektif Gender Pada Masa Covid-19. Deputi Bidang Perlindungan Hak Perempuan.

Prasetya, E. (2018). Pemberdayaan Masyarakat Tentang Kesehatan, Pendidikan dan Kreatifitas. Abdi Dosen: Jurnal Pengabdian Pada Masyarakat 2 (1), 19-25.

Satuan Tugas Penanganan COVID-19. (2020). Data persebaran Covid-19. https://covid19.go.id/

Yuliana. (2020). Corona Virus Diseases(Covid-19); Sebuah Tinjauan Literatur. Wellness And Healthy Magazine, Vol. 2, No. 1. 